\title{
Germinability after desiccation, storage and cryopreservation of seeds from endemic Encholirium Mart. ex Schult. \& Schult. f. and Dyckia Schult. \& Schult. f. species (Bromeliaceae)
}

\author{
Erika Tarré1 ${ }^{1}$ Bárbara Balzana Mendes Pires ${ }^{1}$, Ana Paula Mançano Guimarães ${ }^{1}$, Leonardo Alves Carneiro ${ }^{1}$, \\ Rafaela Campostrini Forzza² and Elisabeth Mansur ${ }^{1,3}$
}

Received: September 22, 2006. Accepted: February 9, 2007

\begin{abstract}
RESUMO - (Germinabilidade de sementes de espécies endêmicas de Encholirium Mart. ex Schult. \& Schult. f. e Dyckia Schult. \& Schult. f. (Bromeliaceae) após dessecação, armazenamento e criopreservação). O armazenamento de sementes requer a determinação prévia das condições ótimas de temperatura e luz para a germinação, assim como da tolerância à dessecação e a baixas temperaturas. O objetivo deste trabalho foi o estudo do efeito da dessecação, armazenamento a baixa temperatura e criopreservação de seis espécies de Encholirium e duas de Dyckia, selecionadas de acordo com critérios de vulnerabilidade. A germinabilidade de sementes recém-coletadas variou entre 35 e $95 \%$. As sementes apresentaram comportamento fotoblástico, uma vez que a presença de luz foi necessária para induzir a germinação ou aumentar sua eficiência. A dessecação não afetou significativamente a germinabilidade das sementes testadas, com exceção de $E$. heloisae e E. scrutor. Sementes dessecadas e armazenadas durante um ano a $4 \mathrm{e}-20^{\circ} \mathrm{C}$ não apresentaram alterações na germinabilidade, exceto em E. pedicellatum. A germinabilidade após congelamento em nitrogênio líquido foi maior que ou similar à obtida no controle, em todas as espécies estudadas. Entretanto, em E. pedicellatum a tolerância ao congelamento só foi obtida após dessecação das sementes a um conteúdo hídrico de $2,5 \%$. Considerando a tolerância à dessecação e ao armazenamento em baixas temperaturas, as sementes estudadas podem ser classificadas como ortodoxas e conservadas ex situ.
\end{abstract}

Palavras-chave: Cadeia do Espinhaço, conservação de sementes, criopreservação, germinação, sementes ortodoxas

\begin{abstract}
Germinability after desiccation, storage and cryopreservation of seeds from endemic Encholirium Mart. ex Schult. \& Schult. f. and Dyckia Schult. \& Schult. f. species (Bromeliaceae)). Seed storage procedures require previous determination of optimal temperature and light conditions for germination, as well as of tolerance to desiccation and low temperatures. The aim of this paper was to study the effects of desiccation, storage at low temperatures and cryopreservation on the germinability of seeds of six Encholirium and two Dyckia species, which were selected according to vulnerability criteria. Initial germinability of newly harvested seeds varied from 35 to $95 \%$. Seeds presented photoblastic behaviour since light was necessary to induce or increase germination. Except for E. heloisae and E. scrutor, desiccation did not affect significantly the germinability of tested seeds. Storage for one year at 4 and $-20^{\circ} \mathrm{C}$ did not affect the germinability of desiccated seeds, except for E. pedicellatum. Germinability after freezing in liquid nitrogen was higher than or similar to control seeds for all species. However, freezing tolerance of E. pedicellatum seeds was only achieved after desiccation to $2.5 \%$ moisture content. As regards tolerance to desiccation and to storage at low temperatures, the seeds studied here can be classified as orthodox and conserved ex situ.
\end{abstract}

Key words: cryopreservation, Espinhaço mountain range, germination, orthodox seeds, seed conservation

\section{Introduction}

Pitcairnioideae is one of the three subfamilies of Bromeliaceae, including 16 genera that are represented in Brazil by two endemic taxa, Dyckia and Encholirium (Forzza \& Wanderley 1998). Great part of the Brazilian species of this subfamily is concentrated in Espinhaço mountain range (Minas Gerais, Brazil), a region characterized by rupestral field vegetation (Forzza \& Wanderley 1998), in which the Bromeliaceae family plays an important part. Surveys of the area have demonstrated the existence of a high diversity and level of endemism, especially among members of Pitcairnioideae. Thus, bromeliad species occurring in this region are important for a better understanding of genus delimitation and phylogenetic lines (Giulietti et al. 1987). However, as a consequence of several impacts, such as selective exploitation, fire

\footnotetext{
1 Universidade do Estado do Rio de Janeiro, Departamento de Biologia Celular e Genética, Laboratório de Micropropagação e Transformação de Plantas, Rua São Francisco Xavier 524 - PHLC, sala 505, 20550-013 Rio de Janeiro, RJ, Brasil

2 Instituto de Pesquisa Jardim Botânico do Rio de Janeiro, Rua Pacheco Leão 915, 22460-030 Rio de Janeiro, RJ, Brasil

3 Corresponding Author: mansur@uerj.br
} 
and devastation of habitats by urbanization, many endemic species of Espinhaço mountain range are seriously threatened, requiring protection by conservation programs.

As in situ conservation of species with restricted endemism relies on conservation practices that are not always rigorously applied or respected, complementary strategies by ex situ germplasm banks are recommended. Seed storage is the most used method for ex situ conservation, since seeds are the natural structures of plant reproduction and each one may represent a potentially unique and genetically different plant. In addition to being a cost-effective method, sampling and storage of seeds from natural populations are important to support restoration programs (VasquézYanes \& Aréchiga 1996; Slageren 2003). Although the rupestral field vegetation of Espinhaço mountain range has been studied for many years, there is lack of information about seed biology of native species (Madeira \& Fernandes 1999).

The evaluation of seed storage behaviour is the first step for the establishment of storage conditions, including information on temperature and light requirements for germination, desiccation tolerance and freezing sensitivity. However, seed germination is one of the less studied aspects of bromeliad reproduction, as optimal temperatures and light requirement for germination were only evaluated in about 50 of the 2700 species of the family (Downs 1963; Mercier \& Guerreiro Filho 1990).

Maintenance of seed viability after storage can be achieved by adjusting the moisture content to a critical level and by reducing the temperature. Since insufficient drying may result in less than maximum longevity, and over-drying may reduce seed physiological quality (Walters et al. 1998), the moisture level at which viability of seeds can be maintained after long periods must be evaluated.

Cryostorage techniques have an important application for preserving endangered species (Touchell \& Dixon 1994), allowing seeds to be stored for indefinite periods of time at ultra-low temperatures that reduce metabolic rates and deterioration. In these systems, the problems of traditional seed storage, such as DNA damages, requirement for periodic evaluations, viability control, risk of loss by disease and environmental problems are reduced or even eliminated (Benson et al. 1996; Moukadiri et al. 1999; Pita et al. 1998). Although cryogenic storage has been carried out for seeds of many species (Gonzales-Benito et al. 1998; Salomão 2002; Popova et al. 2003), in some cases problems such as abnormal germination or death by internal injuries have been reported (Vertucci 1989). These problems are generally associated with seed characteristics such as size, moisture content and chemical composition (Belletti et al. 1990). Thus, the effect of freezing must be analysed on each species before proposing cryopreservation as a conservation method.

In the present work, six endemic species of Encholirium Mart. ex Schult. \& Schult. f. and two of Dyckia Schult. \& Schult. f. occurring at Espinhaço mountain range were selected according to vulnerability criteria. The list of endangered species of Minas Gerais State (Mendonça \& Lins 2000) includes E. heloisae (L.B. Sm.) Forzza \& Wand. as vulnerable to extinction, adopting the IUCN categories. E. pedicellatum (Mez.) Rauh and Dyckia ursina L.B. Sm. were considered as critically endangered. E. reflexum Forzza \& Wand., E. magalhaesii L.B. Sm., E. subsecundum (Baker) Mez., E. scrutor (L.B. Sm.) Rauh and D. sordida Baker were not included in the list, but are also exposed to risk of genetic erosion or even extinction (Forzza et al. 2003). Germination, desiccation tolerance, germinability after storage, and cryocapability of seeds of these species were investigated to explore the possibilities for their ex situ conservation.

\section{Material and methods}

Seed material - Seed harvest was performed according to the dispersion periods of the chosen species. Seeds of Encholirium reflexum, E. magalhaesii, E. subsecundum, E. scrutor and E. pedicellatum were harvested at Diamantina city and E. heloisae, Dyckia sordida and D. ursina at Serra do Cipó National Park, Espinhaço mountain range, Minas Gerais State, in May and July 2003. The region presents a mesotermic climate $(\mathrm{CwB}$ according to the Köppen system) with a dry season from May to August and a rainy season from September to April, with an average precipitation around $1350 \mathrm{~mm}$. The average annual temperature ranges between 25 and $30{ }^{\circ} \mathrm{C}$ in the summer and 8 to $18{ }^{\circ} \mathrm{C}$ in the winter (Madeira \& Fernandes 1999).

In order to obtain representative seed samples of the local population, 10-12 fruits per plant were collected from at least ten individuals. Fruits with opened capsules were considered as mature. Samples consisted of 500-1000 mixed seeds of each species. Considering that the populations were formed by a low number of individuals and that not all of them set flower, 
these were the maximum amounts of seeds that could be colleted. Consequently, the germination and storage experiments were performed with a lower than the usually recommended number of seeds.

Germination experiments - Three temperatures (20, 25 , and $30^{\circ} \mathrm{C}$ ) were selected for this study, based on the natural thermal conditions. Four groups comprising ten seeds of Encholirium pedicellatum, E. scrutor, Dyckia sordida and D. ursina, and 25 seeds of E. heloisae, E. reflexum, E. magalhaesii and E. subsecundum were prepared. Seeds were placed on filter paper moistened with distilled water in germination boxes and incubated in a germination chamber set with frontal illumination, in one row near the outer edge of shelves, under $16 \mathrm{~h}$ of light $\left(36 \mu \mathrm{mol} \mathrm{m} \mathrm{m}^{-2} \mathrm{~s}^{-1}\right)$ and $8 \mathrm{~h}$ of darkness. Visible radicle protrusion was used to define germination. To evaluate germination in darkness, a second set of seeds was placed in black germination boxes that were opened only after 30 days of incubation. To ensure that no systematic effect occurred due to position within the chamber, boxes were randomly re-arranged periodically.

Desiccation experiments - The desiccation tolerance of seeds was evaluated by comparing the germination percentages of newly harvested and desiccated seeds. In order to promote desiccation, seeds were placed in jars containing silica gel for four to six weeks according to the species. Moisture content (mc) and germination percentages were determined at weekly intervals. Moisture content was evaluated using four samples of ten (Encholirium pedicellatum, E. scrutor, Dyckia sordida and D. ursina) or 25 (E. heloisae, E. reflexum, E. magalhaesii and E. subsecundum) newly harvested seeds on a fresh mass basis by heating at $103{ }^{\circ} \mathrm{C} \pm 5$ during $24 \mathrm{~h}$ (Brasil 1992). To evaluate the germination percentage of desiccated seeds, four replicates with the same number of seeds as above mentioned were placed in germination boxes on filter paper moistened with distilled water and incubated in a germination chamber set at $25^{\circ} \mathrm{C}$ under $16 \mathrm{~h}$ of light and $8 \mathrm{~h}$ of darkness. Germination percentages were determined as described above.

Storage experiments - Seeds were stored in Falcon tubes at 4 and $-20{ }^{\circ} \mathrm{C}$ during 12 months with different moisture contents, including the lowest mc achieved in the desiccation experiments. Encholirium pedicellatum, E. scrutor, Dyckia sordida and $D$. ursina, which produced lower amounts of seeds, were only stored with the lowest mc. For the same reason, E. pedicellatum, E. scrutor and D. ursina were stored only at $4{ }^{\circ} \mathrm{C}$. After the storage period, seeds were germinated at $25{ }^{\circ} \mathrm{C}$ as described above. Preliminary experiments demonstrated that Encholirium and Dyckia seeds stored in Falcon tubes for one year do not show significant alterations in mc.

For cryopreservation experiments, four replicates of ten (Encholirium pedicellatum, E. scrutor, Dyckia sordida, and $D$. ursina) or 25 newly harvested, nondesiccated seeds (E. heloisae, E. reflexum, E. magalhaesii, and E. subsecundum), were placed in $2 \mathrm{~mL}$ cryovials and immersed in liquid nitrogen $\left(-196{ }^{\circ} \mathrm{C}\right)$ during $24 \mathrm{~h}$. Four replicates of ten $E$. pedicellatum seeds were also desiccated to $2.5 \% \mathrm{mc}$ before immersion in liquid nitrogen. Thawing took place at room temperature. Germination percentages were determined and compared to the values displayed by newly harvested seeds.

Statistical analysis - Means and standard deviations of moisture contents and germination percentages were analysed using the GraphPad InStat programme. MannWhitney test was used to compare two groups and Kruskal-Wallis test followed by Dunn post-test was adopted to compare three groups $(\alpha=0.05)$.

\section{Results}

Effect of temperature and light on seed germination Germination of newly harvested seeds under light started, in general, within four days of incubation. Maximum germinability was achieved after different incubation periods according to the species. No further germination was observed after four weeks and nongerminated seeds were often infected by fungi. No significant differences were observed in the germinability of Encholirium species and Dyckia ursina seeds at the different temperatures tested. On the contrary, D. sordida seeds incubated at $30{ }^{\circ} \mathrm{C}$ showed a significantly lower germinability as compared to those incubated at 20 and $25{ }^{\circ} \mathrm{C}$. Maximum germination of seeds incubated at 25 and $30{ }^{\circ} \mathrm{C}$ occurred within 16 days, while at $20{ }^{\circ} \mathrm{C}$ longer incubation periods were required, except for $D$. sordida, D. ursina, $E$. reflexum and E. pedicellatum. No germination occurred when Encholirium seeds were incubated under darkness. Absence of light reduced significantly the germinability of Dyckia seeds in all tested temperatures (Tab. 1).

Seed desiccation tolerance - Seeds of Encholirium magalhaesii, E. reflexum, E. subsecundum, 
780 Tarré, Pires, Guimarães, Carneiro, Forzza \& Mansur: Germinability after desiccation, storage and cryopreservation...

Table 1. Effect of temperature and light on the germination of freshly harvested Encholirium and Dyckia seeds.

\begin{tabular}{|c|c|c|c|c|c|c|}
\hline \multirow[t]{2}{*}{ Species } & \multirow[t]{2}{*}{ Temperature $\left({ }^{\circ} \mathrm{C}\right)$} & \multicolumn{5}{|c|}{ Maximum Germinability ( $\%$; mean \pm S.D.) } \\
\hline & & & Light* & & Darkness** & Period (days) \\
\hline \multirow{3}{*}{ E. heloisae } & 20 & 80.0 & \pm 12.0 & $\mathrm{a}$ & 0 & 30 \\
\hline & 25 & 95.0 & \pm 5.8 & $\mathrm{a}$ & 0 & 11 \\
\hline & 30 & 90.0 & \pm 11.6 & $\mathrm{a}$ & 0 & 16 \\
\hline \multirow{3}{*}{ E. magalhaesii } & 20 & 90.0 & \pm 5.3 & $\mathrm{a}$ & 0 & 30 \\
\hline & 25 & 93.0 & \pm 8.7 & $\mathrm{a}$ & 0 & 9 \\
\hline & 30 & 85.0 & $\pm \quad 0$ & $\mathrm{a}$ & 0 & 9 \\
\hline \multirow{3}{*}{ E. reflexum } & 20 & 78.0 & \pm 9.3 & $\mathrm{a}$ & 0 & 16 \\
\hline & 25 & 75.0 & \pm 12.1 & $\mathrm{a}$ & 0 & 9 \\
\hline & 30 & 80.0 & \pm 12.0 & $\mathrm{a}$ & 0 & 16 \\
\hline \multirow{3}{*}{ E. subsecundum } & 20 & 60.0 & \pm 6.4 & $\mathrm{a}$ & 0 & 30 \\
\hline & 25 & 63.0 & $\pm \quad 3.5$ & $\mathrm{a}$ & 0 & 7 \\
\hline & 30 & 73.0 & \pm 13.9 & $\mathrm{a}$ & 0 & 16 \\
\hline \multirow{3}{*}{ E. pedicellatum } & 20 & 90.0 & \pm & $\mathrm{a}$ & 0 & 16 \\
\hline & 25 & 80.0 & \pm & $\mathrm{a}$ & 0 & 7 \\
\hline & 30 & 90.0 & \pm 11.6 & $\mathrm{a}$ & 0 & 9 \\
\hline \multirow{3}{*}{ E. scrutor } & 20 & 50.0 & \pm 22.0 & $\mathrm{a}$ & 0 & 30 \\
\hline & 25 & 60.0 & \pm 12.1 & $\mathrm{a}$ & 0 & 16 \\
\hline & 30 & 55.0 & \pm 16.7 & $\mathrm{a}$ & 0 & 16 \\
\hline \multirow{3}{*}{ D. sordida } & 20 & 50.0 & \pm 11.0 & $\mathrm{a}$ & 0 & 11 \\
\hline & 25 & 50.0 & \pm 11.5 & $\mathrm{a} A$ & $10.0 \pm 0$ a B & 9 \\
\hline & 30 & 35.0 & \pm 5.2 & $\mathrm{~b} A$ & $10.0 \pm 0.4$ a B & 7 \\
\hline \multirow{3}{*}{ D. ursina } & 20 & 85.0 & $\pm \quad 6.4$ & $\mathrm{a} A$ & $50.0 \pm 1.0$ a B & 15 \\
\hline & 25 & 70.0 & \pm 11.0 & $\mathrm{a} A$ & $20.0 \pm 0 \mathrm{~b} \mathrm{~B}$ & 11 \\
\hline & 30 & 79.0 & $\pm \quad 5.0$ & $\mathrm{a} A$ & $30.0 \pm 1.0 \mathrm{ab} \mathrm{B}$ & 11 \\
\hline
\end{tabular}

* Seeds incubated in germination chamber set under $16 / 8 \mathrm{~h}$ light/darkness; **Seeds incubated in black germination boxes; Different lower case letter indicates significant effect of temperature in the germinability of each species (Kruskal-Wallis test followed by Dunn post-test; $P<0.05)$ and different capital letter indicates significant differences in each line (Mann-Whitney test; $P<0.05$ ). S.D.: standard deviation.

E. pedicellatum, Dyckia sordida and D. ursina were not significantly affected by desiccation, maintaining a high germinability even at low mc values. However, desiccation of E. heloisae and E. scrutor seeds led to a significant reduction in germinability (Tab. 2).

Seed storage behaviour - Seed germinability was differently influenced by mc according to the species and the storage temperature (Tab. 3). Except for Encholirium pedicellatum, in all other cases specific combinations of $\mathrm{mc}$ and storage temperatures were required in order to maintain the same germinability displayed by newly harvested seeds. A significant increase on germinability of E. magalhaesii seeds was observed after desiccation to $4.6 \% \mathrm{mc}$ and storage at 4 and $-20^{\circ} \mathrm{C}$. In E. subsecundum germinability was improved upon seed desiccation to $2.5 \% \mathrm{mc}$ and storage at the same temperatures.

The germinability of seeds of Encholirium heloisae, E. reflexum, E. scrutor, Dyckia sordida and $D$. ursina after cryostorage was similar to that observed in control samples. In addition, a significant increase in germinability was observed in E. magalhaesii and E. subsecundum. However, freezing tolerance of $E$. pedicellatum seeds was only achieved after desiccation to $2.5 \%$ mc (Tab. 4).

\section{Discussion}

The establishment of optimal temperatures for seed germination is a fundamental procedure for seed recovery after storage since sub or supra-optimal temperatures can reduce germinability (Carvalho \& Nakagawa 1988). In this work, the time required for maximum germination of seeds from both genera was shorter at 25 and $30{ }^{\circ} \mathrm{C}$ than at $20{ }^{\circ} \mathrm{C}$. Mercier \& Guerreiro Filho (1990) reported a similar temperature 
Table 2. Effect of moisture contents on the germination of Encholirium and Dyckia seeds desiccated in silica gel and incubated at $25{ }^{\circ} \mathrm{C}$ for a maximum period of 30 days in a germination chamber set at $16 / 8 \mathrm{~h} \mathrm{light/darkness.}$

\begin{tabular}{|c|c|c|c|c|}
\hline \multirow[t]{2}{*}{ Species } & \multicolumn{2}{|c|}{ Moisture Content (\%) } & \multicolumn{2}{|c|}{ Germinability (\%; mean \pm S.D.) } \\
\hline & Newly harvested & Desiccated & Newly harvested & Desiccated \\
\hline E. heloisae & $19.0 \pm 5.0 \mathrm{a}$ & $3.7 \pm 2.7 b$ & $95.0 \pm 0 \mathrm{a}$ & $65.0 \pm 15.0 \mathrm{~b}$ \\
\hline E. magalhaesii & $14.6 \pm 0.9 \mathrm{a}$ & $3.6 \pm 2.6 \mathrm{~b}$ & $90.0 \pm 5.0 \mathrm{a}$ & $90 \pm$ \\
\hline E. reflexum & $11.2 \pm 0.8 \mathrm{a}$ & $4.2 \pm 4.2 \mathrm{~b}$ & $72.0 \pm 9.7 \mathrm{a}$ & $55.0 \pm 25.0 \mathrm{a}$ \\
\hline E. subsecundum & $12.7 \pm 0.8$ a & $4.3 \pm 0.6 \mathrm{~b}$ & $65 \pm 5.0 \mathrm{a}$ & $60.0 \pm$ \\
\hline E.pedicellatum & $13.7 \pm 4.0$ a & $2.5 \pm 1.1 \mathrm{~b}$ & $95.0 \pm 5.0 \mathrm{a}$ & $90.0 \pm 10.0 \mathrm{a}$ \\
\hline E. scrutor & $24.0 \pm 2.2 \mathrm{a}$ & $2.5 \pm 0.9 \mathrm{~b}$ & $80.0 \pm 15.0 \mathrm{a}$ & $45.0 \pm 5.0 \mathrm{~b}$ \\
\hline D. sordida & $13.4 \pm 5.9 \mathrm{a}$ & $2.6 \pm 2.0 \mathrm{~b}$ & $53.0 \pm 7.5 \mathrm{a}$ & $50.0 \pm 10.0 \mathrm{a}$ \\
\hline D. ursina & $28.2 \pm 1.9 \mathrm{a}$ & $2.5 \pm 0.73 \mathrm{~b}$ & $65.0 \pm 15.0 \mathrm{a}$ & $65 \pm 5.0 \mathrm{a}$ \\
\hline
\end{tabular}

Different lower case letter indicates significant differences in each line, within characteristics (Mann-Whitney test; $P<0.05$ ). S.D.: standard deviation.

effect on the germination rate of other bromeliads.

Light is one of the main factors controlling dormancy (Pons 1992), which is decisive for the survival of seedlings in the field. The light response depends both on the genotype and on environmental conditions during seed ontogenesis (Válio \& Scarpa 2001). Encholirium seeds presented an absolute photoblastism since germination only occurred under light. Because low germination frequencies were observed when Dyckia seeds were incubated under darkness, they were considered preferential photoblastic (Klein \& Felippe 1991). This behaviour can influence the natural germination of seeds, impairing the occupation of different microhabitats such as cracks in tree trunks or soil covered by rocks (Baskin \& Baskin 2001), and contributing to the restricted number of individuals found in the populations. Lack of germination in darkness was also observed in seeds of other bromeliad species such as Pitcairnia flammea Lindl., Vriesea haematina L.B. Sm. and Puya berteroniana Mez. (Benzing 2000).

The increase in germinability of desiccated seeds of Encholirium magalhaesii and E. subsecundum

Table 3. Effect of cold storage on the germinability of Encholirium and Dyckia seeds with different moisture contents, stored in Falcon tubes at 4 and $-20^{\circ} \mathrm{C}$ for one year, followed by incubation at $25^{\circ} \mathrm{C}$ in a germination chamber set at $16 / 8 \mathrm{~h} \mathrm{light/darkness} \mathrm{during} 30$ days .

\begin{tabular}{|c|c|c|c|c|c|}
\hline \multirow{3}{*}{$\begin{array}{l}\text { Species } \\
\text { E. heloisae }\end{array}$} & \multirow{3}{*}{$\begin{array}{c}\text { Moisture Content } \\
(\%) \\
8.0 \pm 0.8\end{array}$} & \multicolumn{4}{|c|}{ Germinability (\%; mean \pm S.D.) } \\
\hline & & \multicolumn{2}{|l|}{ Initial } & \multirow{2}{*}{$\begin{array}{l}\text { Stored at } 4{ }^{\circ} \mathrm{C} \\
78.0 \pm 5.2 \mathrm{~b}\end{array}$} & \multirow{2}{*}{$\begin{array}{r}\text { Stored at }-20{ }^{\circ} \mathrm{C} \\
85.0 \pm 2.0 \mathrm{ab}\end{array}$} \\
\hline & & $100.0 \pm$ & $\mathrm{a}$ & & \\
\hline & $4.2 \pm 0.4$ & $95.0 \pm 0$ & $a b$ & $96.0 \pm 0 \mathrm{a}$ & $85.0 \pm 3.8 \mathrm{~b}$ \\
\hline \multirow[t]{4}{*}{ E. magalhaesii } & $11.0 \pm 0.4$ & $92.0 \pm 4.6$ & $\mathrm{a}$ & $93.0 \pm 2.0 \mathrm{a}$ & $93.0 \pm 2.0 \mathrm{a}$ \\
\hline & $6.2 \pm 0.4$ & $85.0 \pm 11.5$ & $\mathrm{a}$ & $93.0 \pm 2.0 \mathrm{a}$ & $92.0 \pm 3.3 \mathrm{a}$ \\
\hline & $4.6 \pm 1.2$ & $80.0 \pm 0$ & $\mathrm{~b}$ & $92.0 \pm 3.3 \mathrm{a}$ & $91.0 \pm 2.0 \mathrm{ab}$ \\
\hline & $1.3 \pm 0.2$ & $100 \pm$ & $\mathrm{a}$ & $94.0 \pm 2.3 \mathrm{~b}$ & $94.0 \pm 2.3 b$ \\
\hline \multirow[t]{3}{*}{ E. reflexum } & $7.8 \pm 1.8$ & $65.0 \pm 14.4$ & $\mathrm{a}$ & $60.0 \pm 1.6 \mathrm{a}$ & $72.0 \pm 2.3 \mathrm{a}$ \\
\hline & $5.0 \pm 0.2$ & $55.0 \pm 3.0$ & $\mathrm{a}$ & $61.0 \pm 1.9 \mathrm{a}$ & $66.0 \pm 1.1 \mathrm{a}$ \\
\hline & $1.9 \pm 0.3$ & $74.0 \pm 12.7$ & $\mathrm{a}$ & $68.0 \pm 3.6 \mathrm{a}$ & $66.0 \pm 3.5 \mathrm{a}$ \\
\hline \multirow[t]{3}{*}{ E. subsecundum } & $8.0 \pm 2.1$ & $82.0 \pm 2.3$ & $\mathrm{a}$ & $76.0 \pm 4.6 \mathrm{a}$ & $74.0 \pm 5.2 \mathrm{a}$ \\
\hline & $5.0 \pm 1.5$ & $90.0 \pm 11.5$ & $\mathrm{a}$ & $77.0 \pm 6.0 \mathrm{ab}$ & $66.0 \pm 2.3 b$ \\
\hline & $2.5 \pm 1.4$ & $47.5 \pm 2.9$ & $\mathrm{~b}$ & $61.0 \pm 3.8 \mathrm{ab}$ & $75.0 \pm 3.8 \mathrm{a}$ \\
\hline E. pedicellatum & $2.5 \pm 0.5$ & $90.0 \pm 11.5$ & $\mathrm{a}$ & $50.0 \pm 0.8 \mathrm{~b}$ & $\mathrm{NE}$ \\
\hline E. scrutor & $2.7 \pm 0.5$ & $45.0 \pm 5.8$ & $\mathrm{a}$ & $55.0 \pm 5.8 \mathrm{a}$ & NE \\
\hline D. sordida & $5.0 \pm 1.5$ & $70.0 \pm 0.8$ & $\mathrm{a}$ & $55.0 \pm 5.8 \mathrm{~b}$ & $70.0 \pm 0.8 \mathrm{a}$ \\
\hline D. ursina & $2.5 \pm 0.4$ & $65.0 \pm 5.8$ & $\mathrm{a}$ & $60.0 \pm 11.5 \mathrm{a}$ & $\mathrm{NE}$ \\
\hline
\end{tabular}

NE: Not evaluated; In each line, different letters indicate significant differences among treatments for each species by Kruskal-Wallis test followed by Dunn post-test or Mann-Whitney test $(P<0.05)$. S.D.: standard deviation. 
Table 4. Effect of freezing in liquid nitrogen $\left(-196^{\circ} \mathrm{C}\right)$ during 24 hours on the germinability of newly harvested Encholirium and Dyckia seeds. Control seeds were evaluated without freezing.

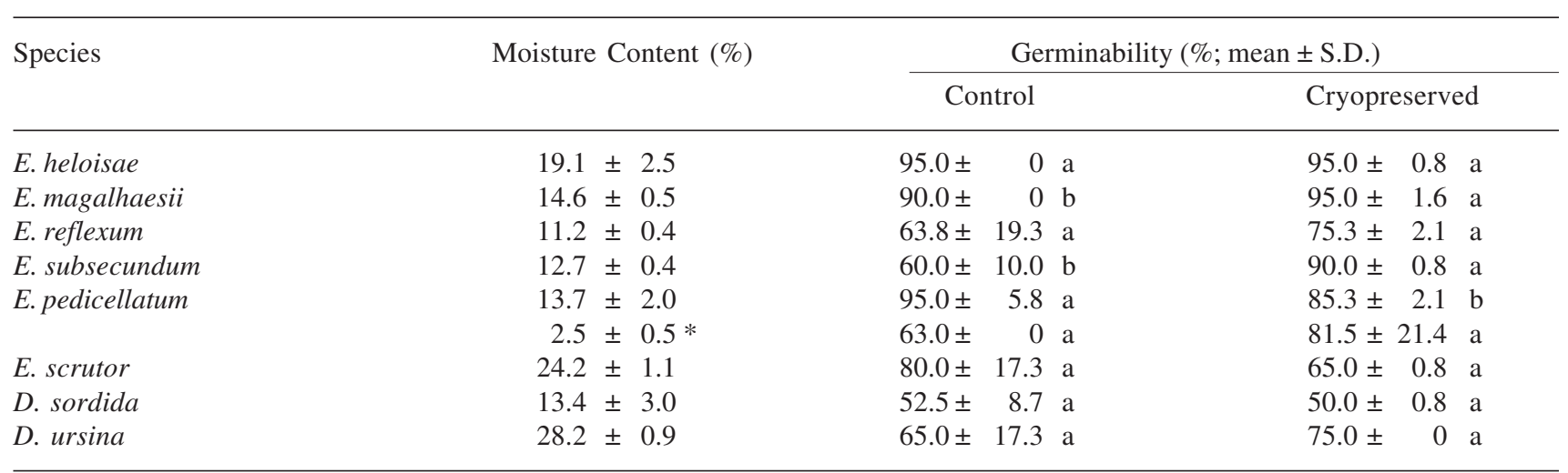

* Desiccated seeds; In each line different letters indicate significant differences by Mann-Whitney test $(P<0.05)$. S.D.: standard deviation.

after storage at 4 and $-20^{\circ} \mathrm{C}$ can be due to the natural desiccation that occurs prior to germination, particularly in species from areas with a pronounced dry season, such as the rupestral fields. The promotive effect of artificial drying on germination was interpreted by Tompsett \& Pritchard (1998) as a continuation of the maturation process occurring naturally when seeds become drier. In addition, increasing of seed germination by chilling has been reported in a range of species (Gosling 1989) and a decrease in ABA content after cold stratification in dormant seeds was described in apple (Lee \& Looney 1978) and Acer L. species (Pinfield et al. 1987). As suggested for other species (Powell 1987), it is possible that $\mathrm{ABA}$ reduction is involved in dormancy loss and subsequent germination.

The freezing sensitivity of seeds stored in liquid nitrogen was investigated in order to propose the use of cryopreservation techniques for Encholirium and Dyckia species. As a general rule, cryopreservation of orthodox seeds can be successfully undertaken when seeds naturally have low moisture contents. According to Standwood (1985), moisture contents ranging between 10 and $30 \%$ could lead to a decrease in seed survival after cryopreservation due to the formation of intracellular ice during the freezingthawing process. However, except for E. pedicellatum, germination of seeds with original moisture contents between 11.2 and $28.2 \%$ was not negatively affected by cryostorage. In fact, germinability of E. magalhaesii and E. subsecundum seeds was increased after freezing.

To our knowledge, this is the first study on seeds of Encholirium and Dyckia. Although the experiments were performed with small samples due to limitations on the number of individuals in the populations and in the number of seeds produced, we can conclude that seeds of the species evaluated here have orthodox storage behaviour according to Roberts (1973) definition, in view of their tolerance to desiccation and low temperatures. In addition, we demonstrated the cryocapability of the seeds, providing evidence that cryopreservation can also be used for long-term conservation of these species.

\section{References}

Baskin, C.C. \& Baskin, J.M. 2001. Seeds: ecology, biogeography and evolution of dormancy and germination. California, Academic Press.

Belletti, P.; Lanteri, S.; Lepori, G.; Nassi, M.O. \& Quagliotti, L. 1990. Factors related to the cryopreservation of pepper and eggplant seeds. Advanced Horticulture Science 4: 118-120.

Benson, E.; Wilkinson, M.; Todd, A.; Ekuere, V. \& Lyon I. 1996. Development competence and ploidy stability in plants regenerated from cryopreserved potato shoottips. Cryo-Letters 17: 119-128.

Benzing, D.H. 2000. Bromeliaceae: profile of an adaptive radiation. New York, Cambridge University Press.

Brasil. 1992. Ministério da Agricultura e da Reforma Agrária. Regras para análise de sementes. Brasília, SNDA/ DNDV/CLAV.

Carvalho, N.M. \& Nakagawa, J. 1988. Sementes: ciência, tecnologia e produção. $3^{\mathrm{a}}$ ed. Campinas, Fundação Cargill.

Downs, R.J. 1963. Photocontrol of germination of seeds of Bromeliaceae. Phyton 21: 1-6.

Forzza, C.R. \& Wanderley, M.G.L. 1998. Flora of Serra do Cipó, Minas Gerais: Bromeliaceae - Pitcairnioideae. Boletim de Botânica da Universidade de São Paulo 17 : 255-270. 
Forzza, R.C.; Christianini, A.V.; Wanderley, M.G.L. \& Buzato, S. 2003. Encholirium (Pitcairnioideae - Bromeliaceae): conhecimento atual e sugestões para conservação. (Encholirium (Pitcairnioideae - Bromeliaceae): current knowledge and suggestions for conservation). Vidalia 1: 7-20.

Giulietti, A.M.; Menezes, N.L.; Pirani, J.R.; Meguro, M.L. \& Wanderley, M.G.L. 1987. Flora da Serra do Cipó: caracterização e lista de espécies. Boletim de Botânica da Universidade de São Paulo 9: 1-152.

Gonzales-Benito, M.E.; Iriondo, J.M. \& Pérez-Garcia, F. 1998. Seed cryopreservation: an alternative method for conservation of Spanish endemics. Seed Science Technology 26: 257-262.

Gosling, P.G. 1989. The effect of drying Quercus robur acorns to different moisture contents, followed by storage, either with or without imbibition. Forestry 62: 41-50.

Klein, A. \& Felippe, G.M. 1991. Efeito da luz na germinação de sementes de ervas invasoras. Pesquisa Agropecuária Brasileira 26: 955-966.

Lee, J.M. \& Looney, N.E. 1978. Changes in abscisic acid and gibberellin levels in apple seeds during stratification and their relationship to genetic composition. Canadian Journal of Plant Science 58: 761-767.

Madeira, J.A. \& Fernandes, G.W. 1999. Reproductive phenology of sympatric species of Chamaecrista (Leguminosae) in Serra do Cipó, Brazil. Journal of Tropical Ecology 15: 463-479.

Mendonça, M.P. \& Lins, L.V. (orgs.). 2000. Lista vermelha das espécies ameaçadas da flora de Minas Gerais. Belo Horizonte, Fundação Biodiversitas, Fundação ZooBotânica de Belo Horizonte.

Mercier, H. \& Guerreiro Filho, O. 1990. Sexual propagation of some native bromeliads of Mata Atlântica: effect of light and temperature on germination. Hoehnea 17: $19-26$

Moukadiri, O.; Deming J.; O'Connor, J.B. \& Cornyo, M.J. 1999. Phenotypic characterization of the progenies of rice plants derived from cryopreserved calli. Plant Cell Report 18: 625-632.

Pinfield, N.J.; Stutchburry, P.A. \& Bazaid, S.M. 1987. Seed dormancy in Acer: is there a common mechanism for all Acer species and what part is played in it by abscisic acid? Physiologia Plantarum 22: 845-850.
Pita, J.M.; Sanz, V. \& Escudero, A. 1998. Seed cryopreservation of seven Spanish native pine species. Silvae Genetica 47: 220-223.

Pons, T.L. 1992. Seed response to light. Pp. 259-284. In: M. Fenner (ed.). Seeds: the ecology of regeneration in plant communities. New York, CAB International.

Popova, E.V.; Nikishina, T.V.; Kolomeitseva, G.L. \& Popov, A.S. 2003. The effect of seed cryopreservation on the development of protocorms by the hybrid orchid Bratonia. Biodiversity and Conservation 50: 672-677.

Powell, L.E. 1987. Hormonal aspects of bud and seed dormancy in temperature-zone woody plants. HortScience 22: 845-850.

Roberts, E.H. 1973. Predicting the storage life of seeds. Seed Science Technology 1: 499-514.

Salomão, A.N. 2002. Tropical seed species response to liquid nitrogen exposure. Brazilian Journal of Plant Physiology 14: 133-138.

Slageren, V.M.W. 2003. The millenium seed bank: building partnerships in arid regions for the conservation of wild species. Journal of Arid Environment 54: 195-201.

Standwood, P.C. 1985. Cryopreservation of seed germplasm for genetic conservation. Pp. 199-236. In: K.K. Kartha (ed.). Cryopreservation of Plant Cells and Organs. Boca Ratón, CRC Press.

Tompsett, P.B. \& Pritchard, H.W. 1998. The effect of chilling and moisture status on the germination, desiccation tolerance and longevity of Aesculus hippocastanum L. seed. Annals of Botany 82: 249-261.

Touchell, D.H. \& Dixon, K.D. 1994. Cryopreservation for seedbanking of Australian species. Annals of Botany 74: 541-546.

Walters, C.; Rao, N.K. \& Hu, X. 1998. Optimizing seed water content to improve longevity in ex situ genebanks. Seed Science Research 8: 15-22.

Válio, I.F.M. \& Scarpa, F.M. 2001. Germination of seeds of tropical pioneer species under controlled and natural conditions. Brazilian Journal of Botany 24: 79-84.

Vazquéz-Yanes, C. \& Aréchiga, M.R. 1996. Ex situ conservation of tropical rain forest seed: problems and perspectives. Interciência 21: 293-298.

Vertucci, C.W. 1989. Relationship between thermal transitions and freezing injury in pea and soybean seeds. Plant Physiology 90: 1121-1128. 